\title{
The Fight for Clean Technology Funds: Who Should Control the Future of Low-Carbon Technology in the Developing World
}

\author{
William Gardner \\ Indiana University Maurer School of Law
}

Follow this and additional works at: https://www.repository.law.indiana.edu/ijgls

Part of the Energy and Utilities Law Commons, Environmental Law Commons, and the International Law Commons

\section{Recommended Citation}

Gardner, William (2011) "The Fight for Clean Technology Funds: Who Should Control the Future of LowCarbon Technology in the Developing World," Indiana Journal of Global Legal Studies: Vol. 18 : Iss. 1 , Article 19.

Available at: https://www.repository.law.indiana.edu/ijgls/vol18/iss1/19

This Note is brought to you for free and open access by the Law School Journals at Digital Repository @ Maurer Law. It has been accepted for inclusion in Indiana Journal of Global Legal Studies by an authorized editor of Digital Repository @ Maurer Law. For more information, please contactrvaughan@indiana.edu.

\section{$\Psi$}

JEROME HALL LAW LIBRARY

INDIANA UNIVERSITY

Maurer School of Law
Blooming ton 


\title{
The Fight for Clean Technology Funds: Who Should Control the Future of Low-Carbon Technology in the Developing World?
}

\author{
WILLIAM GARDNER*
}

\begin{abstract}
As part of a multilateral climate change treaty, the parties to the United Nations Framework Convention on Climate Change (UNFCCC) have discussed establishing an international aid mechanism, or fund, to support low-carbon energy generation and energy efficiency projects in developing countries. The selection of a fund administrator has been particularly contentious. Many developed countries believe that, rather than creating a new fund, the COP should use an already established one-the World Bank's Clean Technology Fund (CTF)-and select the World Bank as fund administrator. However, many developing countries believe the Conference of the Parties (COP) to the UNFCCC should create a new fund with administrative control retained by the COP. This Note first uses a public choice economic analysis to examine why different countries support different fund administrators. Second, it evaluates the arguments for and against the World Bank's CTF and concludes that the World Bank must make several important changes for the COP to select its fund and give it administrative control. Lastly, this Note discusses how conflict may arise between the World Bank and the United Nations if the COP does not select the World Bank as fund administrator. The United Nations does not have any direct control over the World Bank's decision to continue to operate its fund, but the countries that are parties to the UNFCCC may have a legal obligation to support whichever fund the COP selects.
\end{abstract}

* Executive Articles Editor, Indiana Journal of Global Legal Studies, J.D. Candidate, 2012, Indiana University Maurer School of Law; M.P.A Candidate, 2012, Indiana University School of Public and Environmental Affairs; B.S. magna cum laude, 2006, Auburn University. I would like to thank Professors Robert Fischman and Kenneth Richards, along with Bruce Rich of the Sierra Club, for their valuable comments. I would also like to thank Kathryne Feary and David McNamee for their advice and support.

Indiana Journal of Global Legal Studies Vol. 18 \#1 (Winter 2011)

(C) Indiana University Maurer School of Law 


\section{INTRODUCTION}

Since the 1970s, public international political and financial institutions ${ }^{1}$ have increasingly taken center stage in the debate over international environmental law. The United Nations Conference on the Human Environment in 1972 was the first international conference specifically intended to address environmental problems. ${ }^{2}$ The Conference marked a turning point in that countries recognized the need for widespread collaboration to confront global environmental problems. The Conference established a precedent for using international institutions to facilitate collaboration, ${ }^{3}$ and it led to the creation of the Stockholm Declaration, ${ }^{4}$ a document that typifies one of the central difficulties of international environmental diplomacy - the divide between developed and developing countries. ${ }^{5}$ The Declaration is replete with instances of conflict between developed and developing countries, and even now, almost forty years later, the competing interests of these two groups continue to shape international environmental law.

The United Nations Framework Convention on Climate Change (UNFCCC) builds upon the work of the United Nations Conference on the Human Environment. International institutions play a central role in the climate change debate, and divisions between developed and developing countries perennially affect international negotiations of the Conference of the Parties ${ }^{6}$ (COP) to the UNFCCC. ${ }^{7}$ The root of the division is how developed and developing countries want to allocate responsibility for past and future greenhouse gas (GHG) emissions, but

1. When I refer to "public international institutions," I mean intergovernmental organizations whose members are nation-states and that are concerned with issues of global or international governance.

2. Shawkat Alam, The United Nations' Approach to Trade, The Environment and Sustainable Development, 12 ILSA J. INT'L \& COMP. L. 607, 610 (2006).

3. John C. Dernbach, Sustainable Development as a Framework for National Governance, 49 CASE W. RES. L. REV. 1, 17 (1998).

4. Declaration of the United Nations Conference on the Human Environment, June 16, 1972, 11 I.L.M. 1416.

5. Gaetan Verhoosel, Beyond the Unsustainable Rhetoric of Sustainable Development: Transferring Environmentally Sound Technologies, 11 GEO. INT'L ENVTL. L. REV. 49, 49 \& n.1 (1998).

6. For those unfamiliar with the UNFCCC, it is both the name of a treaty and the name of a United Nations' Secretariat responsible for the operations of the treaty. Also, the COP is the governing body of the UNFCCC, and its members include all the countries that are signatories to the UNFCCC. There are also a number of observer organizations that attend COP meetings.

7. Daniel Bodansky, Current Development: The Copenhagen Climate Change Conference: A Postmortem, 104 AM. J. INT'L L. 230, 232, 234 (2010) (noting the disputes between developed and developing countries during the meetings in Bali and Copenhagen). 
the divide between the two groups extends well beyond that, affecting nearly every facet of climate change negotiations.

International aid money is one of the primary divisions between developed and developing countries. Many countries have expressed the view that developed countries should set aside international aid money to help developing countries purchase clean energy technology. ${ }^{8}$ The aid money would give developing countries an incentive to invest in lowcarbon technology as their economies modernize. Furthermore, because developed countries have used an inequitable share of the atmospheric commons to further their own economic growth, the aid money would also serve as compensation to developing nations.

The debate over clean technology aid, however, is about more than the amount of money; the mechanism used to deliver the money is equally important. ${ }^{9}$ If adequate funding can be amassed, an international organization will need to be selected or created to administer those funds. In fact, several organizations are already posturing for the role of clean technology fund administrator. The World Bank, the Global Environment Facility (GEF), and a new (currently hypothetical) institution created by the COP are the three most likely choices for clean technology fund administrator. In the future, other organizations may vie for the position, but these three organizations appear to be the only options currently available.

After a brief description of these organizations, this Note examines the negotiating positions and motivations of three different groups within the COP: (1) developed countries, including the United States and several European countries; (2) large developing countries that emit substantial amounts of GHGs; and (3) the least developed countries (LDCs) and the small island nations. This section concludes that even though their motivations are not the same, each country wants the same thing: for the clean technology fund administrator to be the institution with which they retain the most influence. However, for some countries, choosing a clean technology fund administrator may have more to do with diplomatic or monetary benefits than a desire to mitigate climate change.

Next, this Note considers which international organization is best suited to be the clean technology fund administrator. This analysis

8. See Group of 77 [G-77], Ministerial Declaration, para. 31 (Sept. 26, 2008), available at $\mathrm{http} / / \mathrm{www} . \mathrm{g} 77 . \mathrm{rg} / \mathrm{doc} / \mathrm{Declaration} 2008 \mathrm{htm}$ (stating that during the thirteenth COP to the UNFCCC the G-77 ministers "urged the intermational community to assist developing countries to address the consequences of climate change particularly through new, additional and predictable financial resources, capacity building, and access to and transfer of technology.').

9. David B. Hunter, Intermational Climate Negotiations: Opportunities and Challenges for the Obama Administration, 19 DUKE ENVTL. L \& POL'Y F. 247, 262 (2009). 
highlights the strengths and weaknesses of the World Bank's CTF, ${ }^{10}$ the GEF, and a new institution that the COP would create. In some respects, a comparison of the institutions is difficult because the final structure of a COP-led clean technology fund is unknown. However, the World Bank's CTF suffers from several important problems, and this section concludes that, without reformation of the Bank's CTF, a new COP-created fund would be a better alternative.

Lastly, this Note explores the legal connection between the World Bank and the United Nations. The World Bank is a specialized agency of the United Nations, ${ }^{11}$ and the two organizations are connected through a number of international agreements. Nevertheless, conflict may arise between the two institutions if the COP does not select the World Bank's CTF. After analyzing the key agreements between the World Bank and the United Nations that relate to the CTF, this Note determines that the United Nations has no legal avenue to force the Bank to shut down its CTF. However, the countries that are parties to the UNFCCC may have a legal obligation to support whichever fund the COP selects as administrator. If countries cannot fulfill their obligations to the UNFCCC by funding the World Bank's CTF, countries may stop funding it.

This Note concludes that although the World Bank's CTF does have several advantages, it also has important structural flaws. Developing countries in the COP are unlikely to vote for the World Bank as clean technology fund administrator because of these flaws. Furthermore, without the support of developing countries for a clean technology fund administrator, it is unlikely that the COP process will result in a climate change treaty. While the COP is not without problems of its own, the UNFCCC currently seems to be the most likely process through which the world will develop a comprehensive climate change treaty.

\section{BACKGROUND}

The World Bank and the COP have both established interim clean technology funds. On July 1, 2008, the World Bank's Board of Directors

10. There are two "clean technology funds" referred to in this Note. The first is the World Bank's CTF, designated by the acronym CTF. The second use of "clean technology fund" is a general reference to the concept of any fund, including one developed by the COP, that provides international aid for low-carbon and energy efficiency projects. When the second meaning is intended, "clean technology fund" is written out.

11. Agreement between the United Nations and the International Bank for Reconstruction and Development, Approved by the General Assembly on November 15, 1947, 2 INT'L ORG. 198, 198, art. I, para. 1 (1948) [hereinafter Agreement between UN and IBRD]. 
approved the Climate Investment Funds (CIF). ${ }^{12}$ The CIF consists of two funds, the Strategic Climate Fund (SCF) and the CTF. ${ }^{13}$ The SCF deals primarily with adaptation financing, ${ }^{14}$ and the CTF "invest[s] in projects ... that contribute to the demonstration, deployment, and transfer of low-carbon technologies."15 As this Note concerns clean technology financing rather than adaptation financing, the CTF will be the focus of further inquiry.

The United Nations uses four different financial institutions for climate change-related projects in developing countries: (1) the Global Environment Facility (GEF); (2) the Adaptation Fund (AF); (3) the Special Climate Change Fund (SCCF); and (4) the Least Developed Countries Fund (LDCF). The GEF administers the SCCF and LDCF, 16 but the COP of the UNFCCC created the two funds. The COP of the UNFCCC also created the AF, which is managed by the Adaptation Fund Board in conjunction with the GEF. ${ }^{17}$ The AF and the LDCF finance adaptation projects, ${ }^{18}$ while the GEF and SCCF finance both adaptation and clean technology projects. ${ }^{19}$

In some respects, the GEF represents a bridge between the World Bank and the COP. The World Bank initially started the GEF in 1991, but it is now an independent organization. ${ }^{20}$ However, the World Bank still serves as the trustee of the GEF trust fund and provides

12. World Bank Group, Climate Investment Funds: History, CLIMATE INVESTMENT FuNDS, http:/www.climateinvestmentfunds.org/cif/designprocess (last visited Oct. 17, 2010).

13. Id.

14. Adaptation financing supports projects that allow human beings and ecosystems to cope with the environmental changes brought about by climate change. Clean technology financing supports projects that mitigate or slow the process of climate change by reducing greenhouse gas emissions.

15. David R. Downes et al., International Environmental Law, 43 INT'L LAW. 837, 855 (2009) (quoting Press Release, The World Bank, Climate Investment Funds: Countries Selected for Governing Bodies, U.N. Press Release 2009/120/SDN (Oct. 17, 2008), available at http://web.worldbank.org/WBSITE/EXTERNAL/NEWS/0, contentMDK:21944136 menuPK:510 62077 pagePK:34370 piPK:34424 theSitePK:4607,00.html.).

16. LDC Fund, UNFCCC, http://unfccc.int/cooperation_support/least_developed_countries _portal/ddc_fund/items/4723.php (last visited December 2, 2010); Special Climate Change Fund, UNFCCC, http//unfccc.int/cooperation_and_support/financial_mechanism/special_climate_ change_fund/items/3657.php (last visited December 2, 2010).

17. Adaptation Fund, UNFCCC, http:/unfcoc.int/cooperation_and_support/financial _mechanism/adaptation_fund/items/3659.php (last visited Nov. 17, 2010).

18. See ADAPTATION FUND, http//www.adaptation-fund.org (last visited Aug. 28, 2010); Least Developed Countries Fund, GEF, http:/www.thegef.com/gef/ldcf (last visited Aug. 28, 2010).

19. Climate Change, GEF, http:/www.thegeforg/gef/climate_change (last visited Aug. 28, 2010); Special Climate Change Fund, GEF, http://www.thegef.com/gef/scof (last visited Aug. 28, 2010).

20. What is the GEF?, GEF, http://www.thegef.org/gef/whatisgef (last visited Aug. 28, 2010). 
administrative services, ${ }^{21}$ and the COP approves guidance "on policies, program priorities, and eligibility criteria." 22 In addition, the GEF is the interim agency that administers the LDCF and the SCCF. ${ }^{23}$ Yet, some developing countries are skeptical of using the GEF as a permanent clean technology fund administrator. They believe that the structure of the GEF gives developed countries more power than developing countries. ${ }^{24}$ While the GEF represents a possible alternative to the COP and the World Bank, both developed and developing countries have released statements that indicate that most nations consider the COP and the World Bank the two most likely candidates for clean technology fund administrator.

Recapping the above, Table 1 illustrates how the current financial institutions are organized, although there is some overlap between organizations:

Table 1. International Aid Mechanisms for Climate Change

\begin{tabular}{|l|l|l|}
\hline $\begin{array}{c}\text { Organizations with } \\
\text { Clean Technology and } \\
\text { Adaptation Funds }\end{array}$ & $\begin{array}{l}\text { Funds that Engage in } \\
\text { Adaptation Financing }\end{array}$ & $\begin{array}{l}\frac{\text { Funds that Engage in }}{\text { Clean Technology }} \\
\text { Financing }\end{array}$ \\
\hline The World Bank & Strategic Climate Fund & Clean Technology Fund \\
\hline The United Nations & $\begin{array}{l}\text { Adaptation Fund, Least } \\
\text { Developed Countries } \\
\text { Fund, Special Climate } \\
\text { Change Fund }\end{array}$ & $\begin{array}{l}\text { Special Climate Change } \\
\text { Fund }\end{array}$ \\
\hline $\begin{array}{l}\text { Global Environment } \\
\text { Facility }\end{array}$ & $\begin{array}{l}\text { Global Environment } \\
\text { Facility }\end{array}$ & $\begin{array}{l}\text { Global Environment } \\
\text { Facility }\end{array}$ \\
\hline
\end{tabular}

21. Id.

22. United Nations Conference on Climate Change, Copenhagen, Den., Dec. 7-18, 2009, Report of the GEF to the Fifieenth Session of the Conference to the Parties to the United Nations Framework Convention on Climate Change, 6, U.N. Doc. FCCC/CP/2009/09 (Oct. 27, 2009), available at http://unfecc.int/resource/docs/2009/cop15/eng/09.pdf.

23. See Least Developed Countries Fund (LDCF) and Special Climate Change Fund (SCCF), GEF, http:/www.thegef.org/gef/sites/thegef.org/files/documents/LDCF-SCCF-22Feb2010.pdf (last visited December 2, 2010).

24. Hunter, supra note 9 , at 262-63 (The GEF offers an arguably more democratic structure [than the World Bank] based on double majority-voting, but the GEF's effectiveness and independence in delivering aid has been questioned, particularly by developing countries."). 


\section{Developed and Developing Countries Prefer Different Clean TECHNOLOGY FUND ADMINISTRATORS}

Developing nations would prefer to vest administrative control of the clean technology fund in a new organization created by the COP. ${ }^{25}$ Conversely, many developed countries prefer the World Bank's CTF. ${ }^{26}$ However, countries that support the same organization often have different motivations. This section will explore why different groups of countries support either the World Bank's CTF or a hypothetical, new COP-created fund.

In determining which organization will be selected as clean technology fund administrator, not only the climate is at stake; there are billions of dollars in foreign aid on the negotiating table. Many countries are spending significant time, money, and political capital to negotiate for a clean technology fund that prioritizes the goals that each country holds most dear. This is what public choice theorists refer to as "rent seeking." Rent seeking is "the use of resources for the purpose of obtaining rents for people where the rents themselves come from some activity that has negative social value." 27 One of the most common examples of rent seeking is when a company hires a lobbyist to advocate for favorable legislation. From the company's perspective, there can be a significant return on their lobbying expense, but the lobbying does not provide any benefits to society, for it merely redistributes wealth from taxpayers to special interest groups. On top of that, the lobbyist walks away with his or her fee. Because the lobbying itself costs the company money and society does not gain anything, on the whole, rent seeking results in a net loss in societal wealth. A form of rent seeking also occurs when special interest groups put pressure on their home countries to send diplomats to the COP who will negotiate for a clean technology fund administrator that will be advantageous to the special interest groups' goals. This activity does not create wealth; instead, the intent is to direct aid money to an organization favored by special interest groups. Nevertheless, not all rent seeking should be

25. Matthew Stilwell, G-77 and China propose enhanced financial mechanism for UNFCCC, CHOIKE (Aug. 26, 2008), http:/www.choike.org/2009/eng/informes/7003.html (noting that a representative of the G-77 and China, Bernarditas Muller, stated that the G-77 wishes to create "an effective financial mechanism under the Conference of Parties with the goal of ensuring the full, effective and sustained implementation of the Convention's obligations relating to financial resources").

26. See Henry Paulson et al., Financial Bridge from Dirty to Clean Technology, Fin. TMMES (London) (Feb. 8, 2008), http:/www.ft.com/cms/s/0/43975af2-d5e7-11dc-bbb2-0000779fd2ac. html?nclick_check=1 (advocating for a new clean technology fund administered by the World Bank).

27. Gordon TULLOCK ET AL, GOVERnMent FAILURE: A PRIMER IN PUBLIC CHOICE 43 (2002). 
discouraged. Just because it is economically wasteful to seek a rent does not mean that the goal, or rent itself, has negative societal value. For example, Gordon Tullock notes that it would be rent seeking for an organization to lobby the government for funds to pay for cancer research, but most people would agree that finding a cure for cancer is a laudable goal. ${ }^{28}$

The following examples regarding clean technology fund negotiations should make this distinction clear. Countries are likely to use their resources to negotiate for a clean technology fund administrator for three primary reasons. First, some developed countries believe that influencing the fund will allow them to direct awards to countries with which they are on friendly terms. This could result in diplomatic benefits that manifest through trade or security reciprocity. Second, some developing countries believe that by influencing the fund they can increase the amount of foreign aid they will receive, benefiting certain special interests. The rent being sought here is purely financial. Third, some countries wish to control the clean technology fund administrator because the risks of climate change are so devastating to their country that other benefits pale in comparison. Accordingly, mitigating climate change would be the central goal in these countries.

Clearly not all rents or reasons are of equal worth to society. The first and the second reasons likely have little societal value and are selfinterested. The third reason is still self-interested, but mitigating climate change has great societal value as well. This example is admittedly an exaggeration, though. Countries in the first and second examples want to mitigate climate change too, but they have important secondary motivations for choosing a clean technology fund administrator. Their desire to mitigate climate change should be recognized, but it should be tempered by the knowledge that those countries' secondary motivations may take precedence over their desire to mitigate climate change. Understanding what rents a country is seeking is essential to objectively evaluating their stance on the selection of a clean technology fund administrator. If a country's aims are self-interested, as when based on the first two rationales, then its justifications for choosing one clean technology fund administrator over another should be more critically examined. On the other hand, if a country's goals are in line with the goals of society as a whole, like when relying on the third rationale, then it lends credence to that country's argument. 
This section looks at three groups of countries and attempts to understand each group's motivation. The three groups are: (1) developed countries, including the United States and several European countries; (2) large developing countries that emit substantial amounts of greenhouse gases (GHGs); and (3) the least developed countries (LDCs) and small island nations. Each group was chosen because they represent a key interest group in the climate change debate. This Note assumes that countries are self-interested, but as the prior discussion of rent seeking demonstrates, self-interest can manifest itself in ways that benefit society.

\section{A. Developed Countries Prefer the World Bank's CTF}

Developed countries cannot prevent climate change through GHG reductions in their countries alone. ${ }^{29}$ In fact, reducing emissions is often cheaper in some developing countries. ${ }^{30}$ For example, if land is less expensive in a developing country, terrestrial sequestration ${ }^{31}$ may be cheaper there. Also, the projected rise in GHG emissions in developing countries vastly outpaces the projected rise in developed countries. ${ }^{32}$ If developed countries reduce only their own emissions, global GHG emissions will still rise due to the projected increase in developing countries' emissions. Therefore, developed and developing countries must work together to mitigate climate change. ${ }^{33}$

29. Examining Administration's Proposal to Establish Multilateral Clean Technology Fund: Hearing Before Subcomm. on Domestic and Intl Monetary Policy, Trade, and Tech. of H. Comm. on Fin. Serv., 110th Cong. 3 (2008) (statement of David Wheeler, Senior Fellow, Center for Global Development) ("[N]ational GHG emission targets in the U.S. and other rich countries cannot achieve the necessary reductions in $\mathrm{CO} 2$ and other greenhouse gases."); see also Paul G. Harris, The European Union and Environmental Change: Sharing the Burdens of Global Warming, 17 COLO. J. INT"L ENVTL. L. \& POLY 309, 315 (2006) ("[T] he developed countries cannot by themselves solve this problem; comprehensive participation of the developed countries and the major developing countries is required.").

30. Jeffrey A. Frankel, Greenhouse Gas Emissions 2 (Brookings Institution, Policy Brief No. 52, 1999), available at http://www.brookings.edu/papers/1999/06energy_frankel.aspx.

31. Terrestrial sequestration occurs when plants and trees absorb carbon dioxide. If one plants more trees or, perhaps more likely, refrains from cutting down as many trees, atmospheric carbon dioxide concentrations will likely decrease.

32. Global Greenhouse Gas Data, EPA, http:/www.epa.gov/climatechange/ emissions/globalghg.html (last visited Oct. 17, 2010).

33. See Paulson, supra note 26 (In 2008, the U.S. Secretary of Treasury and the finance ministers of the United Kingdom and Japan echoed this idea, noting that if energy consumption continues along the current path in developing countries, future development will have a greater impact on our climate. "We have no choice but to help developing countries reduce the carbon footprint of development and make their economies climate change resilient.'). 
However, as quickly as developed and developing countries agree that international aid is a necessary part of a climate change treaty, they just as quickly disagree over who should administer the funds. Although there has been some indication that leaders in developed countries are changing their stances, ${ }^{34}$ in general, developed countries support the World Bank's CTF. Furthermore, developed countries' current support for the CTF appears to have carried over into support for the CTF as the long-term clean technology fund used by the COP.

\section{The U.S. Perspective}

In 2008, the Bush Administration expressed its support for the World Bank's CTF 35 and asked Congress to appropriate two billion dollars to the fund over a three-year period. ${ }^{36}$ The first installment of the two billion dollars was supposed to occur in the 2009 fiscal year with a $\$ 400$ million appropriation. When the appropriations bill, House Resolution 1105, was passed in February 2009, however, appropriations to the World Bank's CTF were noticeably absent. ${ }^{37}$ Several legislators were concerned that money appropriated to the CTF would not be used to support what they considered to be clean energy projects. ${ }^{38}$ Because the CTF uses a technology neutral approach to determine which energy projects should receive funding, it could be used to fund fossil fuel power projects. ${ }^{39}$ For instance, if the CTF provides funding for a utility to build a more efficient coal-fired power plant than the utility would otherwise, the CTF is preventing GHG emissions equal to the difference in emissions between the new technology plant and the old technology

34. Ama Marston, Resistance to Bank's Role in Climate Finance as Alternatives Gain Traction, BRETTON WOODS PROJECT (June 17, 2010), http:/www.brettonwoodsproject.org/art566400 ("U]nder pressure the US may be withdrawing from such staunch support for the Bank's role.").

35. See Paulson, supra note 26 (Former Treasury Secretary Paulson explained that "[b]y pooling our efforts to support a new clean technology fund, administered by the World Bank, we can help developing countries bridge the gap between dirty and clean technology.").

36. Martin A. Weiss \& JefFrey Logan, Cong. Research Serv., RS 2289, The Wortd BANK'S CLEAN TECHNOLOGY FUND 2 (2008).

37. Omnibus Appropriations Act, H.R. 1105, 111th Cong. (2009).

38. WEISS \& LOGAN, supra note 36, at 4 ('The primary concern raised in Congress about the CTF involves the types of 'clean' technologies the World Bank may support. Several Members have questioned whether the CTF should be 'technology neutral,' thus allowing CTF resources to fund carbon-based investments. This was the central debate during a June 5, 2008 House Financial Services Committee hearing on the CTF.').

39. See Lisa Friedman, World Bank: Congress Scraps Support for Clean Technology Program that Funds Coal, CLIMATE WIRE, Feb. 25, 2009 (noting the World Bank's criteria allow financing for ultra-supercritical coal-fired power plants with a carbon intensity of less than 0.795 tons per megawatt-hour). 
plant. Several members of Congress were dissatisfied with this technology neutral approach. Consequently, instead of giving money to the CTF, House Resolution 1105 appropriated $\$ 100$ million to the United States Agency for International Development (USAID) for its clean technology investments abroad.40 The funding to USAID was conditioned on the agency including carbon accounting-i.e. "including in project feasibility calculations a cost for the resulting greenhouse gas emissions"- when deciding which projects to fund. ${ }^{41}$ The result of this condition was that it would be nearly impossible for funding to be allocated to coal projects.

Like the Bush Administration, the Obama Administration has also expressed support for the World Bank's CTF. ${ }^{42}$ For the 2010 fiscal year, President Obama asked that $\$ 500$ million be appropriated to the CTF.43 Congress did not appropriate the entire amount, but the Consolidated Appropriations Act of 2010 did provide up to $\$ 300$ million to the CTF. 44 In contrast to Congress's prior concerns, this Act also does not prohibit the CTF from using the appropriated money to fund fossil fuel power projects.

The Obama Administration has also advocated for the international use of the World Bank's CTF. In December 2009, President Obama helped negotiate the Copenhagen Accord, which notes that developed countries should establish an international aid mechanism for climate change with $\$ 100$ billion of annual funding by 2020.45 Since Copenhagen, the Obama Administration has again expressed its support for the World Bank's CTF, stating in a recent submission to the UNFCCC that "[it] would consider it desirable for the [COP] to invite the World Bank to serve as Trustee of the new Fund and, in this regard, to organize a process to take steps to establish the Fund." 46

40. Joel Meister, U.S. Congress Cuts Funds for World Bank's So-Called Clean Technology Fund, CENTER FOR GLOBAL DEv. (Feb. 25, 2009), http://blogs.cgdev.org/globaldevelopment/ 2009/02/us-congress-cuts-funds-for-wor.php.

41. Id.

42. See Lisa Friedman, Climate: Obama Admin Endorses World Bank's Technology Fund, E \& E NEws PM, May 8, 2009 (quoting the President's Climate Change Envoy, Todd Stern, who expressed the administration's support for the CTF).

43. Robin Bravender, Climate: Obama Admin Urges House to Boost Funding for Int'l Programs, ENV'T \& ENERGY DAILY, July 9, 2009.

44. Consolidated Appropriations Act, 22 U.S.C.A. $\$ 7909$ (LexisNexis 2010).

45. See James Kanter, Copenhagen's One Real Accomplishment: Getting Some Money Flowing, N.Y. TIMFS (Dec. 20, 2009), http://www.nytimes.com/2009/12/21/business/energyenvironment/21iht-green21.html.

46. UNFCCC Ad Hoc Working Group on Long-Term Cooperative Action Under the Convention, June 1-11 2010, Additional Views on Which the Chair May Draw in Preparing Text to Facilitate Negotiations Among Parties, 83, U.N. Doc. GE.10-60794 (April 30, 2010), available at http://unfccc.int/resource/docs/2010/awglca10/eng/misc02.pdf. 
The Obama Administration's support for the CTF is likely based on many factors. The U.S. influence over the World Bank's CTF is of particular importance. The United States and the rest of the Group of 8 (G8) were the principal architects of the CTF, and some commentators have argued that the World Bank's CTF gives disproportionate weight to the opinions of these developed countries. ${ }^{47}$ The Administration may believe that the World Bank's CTF is an efficient and accountable aid mechanism and, desiring efficient allocation of funds, the Administration may support the CTF because the United States has greater influence over the World Bank than the COP. This Note examines these claims in a later section and concludes that several of the CTF's procedures do, in fact, favor developed countries.

The United States may operate on the belief that developed countries are better suited to decide how international aid should be allocated. If the United States exerts influence over the CTF, funding may be directed solely to projects in countries that are friendly to U.S. foreign policy or trade goals. In this way, whether acting selfishly or paternalistically, the United States is ignoring fundamental principles of the UNFCCC. The UNFCCC directs that, in providing funding for international aid, developed countries must give full consideration to the special needs of small island nations and the least developed countries. ${ }^{48}$ None of these countries support the World Bank's CTF because the CTF does not recognize their special needs. For international aid money to be used efficiently, developed countries need to see developing countries as partners and recognize that international aid should be used to mitigate climate change, not for some ancillary trade or security goal.

\section{The EU Perspective}

Several European countries helped form the CTF with the United States. The G8, which advised the World Bank on the creation of the CTF, includes four members of the European Union: the United Kingdom, France, Germany, and Italy. ${ }^{49}$ The EU President also

47. Celine Tan, No Additionality, New Conditionality: A Critique of the World Bank's Climate Investment Funds, THIRD WORLD NETWORK, May 30, 2008, at 12-14, available at http:/www.twnside.org.sg/title2/par/Paper.by.Celine.doc.

48. United Nations Framework Convention on Climate Change art. 4 sec. 8, June 4, 1992 June 19, 1993, 31 I.L.M. 849 (entered into force March 21, 1994), available at http:/unfocc.int/resource/docs/convkp/conveng.pdf [hereinafter UNFCCC].

49. Member States, MUSKOKA 2010 G-8, http//g8.gc.ca/about/member-states (last visited Oct. $18,2010)$ 
participates in the G8.50 While not all members of the European Union have indicated that they support the World Bank's fund, G8 support of the CTF shows that at least several powerful EU countries do support it. For instance, in 2008, the United Kingdom, Switzerland, Sweden, Germany, Norway, the Netherlands, and France pledged well over $\$ 2.5$ billion to the Climate Investment Funds (CIF), which includes both the CTF and the SCF. ${ }^{51}$ These countries may be motivated to support the CTF for the same reasons as the United States.

However, just because several EU countries made significant pledges to the World Bank's CTF does not mean that they will in fact provide $\$ 2.5$ billion in funding. The support the United States has given to the CTF is nowhere near the two billion dollars President Bush pledged. Consequently, because the United States has failed to provide the level of funds it pledged, these EU countries may also not provide the full amount of support they originally pledged. ${ }^{52}$ In addition, other climate funds may be gaining increased traction in Europe. For example, Spain recently eschewed the World Bank's CIF and instead provided $\$ 55$ million to the COP's AF. ${ }^{53}$ As the first contribution of its kind, this may set a precedent for other EU countries. ${ }^{54}$ Many European countries may continue to align themselves with the World Bank's CTF, but others may follow Spain's lead.

\section{B. Developing Countries Prefer the COP}

Developing countries' position on the administration of an international clean technology fund has remained the same for many years. In Confronting Climate Change, Kilaparti Ramakrishna and Oran R. Young, two climate change policy experts, point out that as important as "new, additional, and adequate funds" are for developing countries confronting climate change, "[m]any representatives of developing countries have stated clearly that a successful conclusion of a meaningful climate change convention depends upon realizing access

50. Id.

51. Press Release, World Bank, Donor Nations Pledge Over $\$ 6.1$ Billion to Climate Investment Funds, U.N. Press Release 2009/092/SDN (Sept. 26, 2008), available at http://web.worldbank.org/WBSITE/EXTERNAL/NEWS/0,,ontentMDK:21916602 pagePK:3437 0 piPK:34424 theSitePK:4607,00.html.

52. David Wheeler, End of the Road for the World Bank's Clean Technology Fund?, CENTER FOR GLOBAL DEV. (Feb. 25, 2009), http://blogs.cgdev.org/globaldevelopment/2009/02/end-of-theroad-for-the-world.php ("The EU and Japan seem unlikely to support the CTF without the United States ....").

53. Marston, supra note 34.

54. Id. 
to these funds." 55 This analysis from 1992 is just as true today as it was then. "Developing countries have stated over and over again that the climate fund should be controlled by the parties to the convention, and not by existing mechanisms or institutions." 56

Yet one must tread carefully when talking about the will of so-called "developing countries," for the monikers of "developed" and "developing" have begun to lose meaning as the economic gap between some rich and poor countries has shrunk. The term "developing country" seemingly lumps together nations as diverse as China and Burundi, even though China may have more in common with a "developed" country like Japan. The Group of 77 (G-77), a voting bloc that includes 131 developing countries with drastically different interests and needs, exemplifies this point. ${ }^{57}$ The G-77 as a group has issued statements in support of a COPled clean technology fund, ${ }^{58}$ but because of the varied interests of the 131 countries in the G-77, not every country supports a COP-led fund for the same reasons. This section analyzes the motivations of three representative groups of countries within the G-77: large developing countries that are large emitters, small island states, and LDCs. Because small island states and LDCs have similar motivations, they are analyzed together.

\section{Large Developing Countries That Are Large Emitters}

According to a report by the World Resources Institute, China, India, and Brazil are among the top ten countries worldwide for GHG emissions, Gross Domestic Product (GDP), and population. ${ }^{59}$ In fact, by some estimates, China is now the largest emitter of carbon dioxide in the world. ${ }^{60}$ However, unlike many of the other top emitters, China, India, and Brazil have issued statements in conjunction with the G-77

55. Kilaparti Ramakrishna \& Oran R. Young, International Organisations in a Warming World: Building a Global Climate Regime, in ConfronTING CLIMATE Change: Risks, IMPLICATIONS AND RESPONSES 253, 263 (Irving M. Mintzer ed., 1992).

56. Id.

57. Member States of the Group of 77, G-77, http:/www.g77.org/doc/members.html (last visited Oct. 18, 2010).

58. G-77, supra note 8 .

59. KEVIN A. BAUMERT ET AL., WORLD RESOURCES INSTTIUTE, NAVIGATING THE NuMBERS: Greenhouse Gas DATA AND InTERnational Climate Policy 110 (2005), available at http://pdf.wri.org/navigating_numbers.pdf.

60. China Now No. 1 in CO2 Emissions; USA in Second Position, PBL NeTH. ENVTL. ASSESS. AGENCY, http://www.pbl.nl/en/dossiers/Climatechange/moreinfo/ChinanownolinCO2emissionsUSAinseco ndposition.html (last visited Oct. 18, 2010). 
that the COP should control clean technology funds 61 because they believe the COP will provide more equitable representation of aid recipients. ${ }^{62}$

These three countries are comparatively much wealthier than other members of the G-77, but they are nonetheless positioning themselves to receive international aid for clean technology. This is not surprising because, for a number of reasons that will be discussed below, populous developing countries with large economies stand to benefit the most from clean technology aid. Also, China, India, and Brazil can plausibly argue that they should receive clean technology aid because they have relatively low per capita GHG emissions. ${ }^{63}$ However, as their emissions increase over time, their argument loses validity. Large developing countries that are rapidly industrializing will want to have as much political influence on the clean technology fund administrator as possible because it will help them secure clean technology aid in the long term, when their per capita emissions levels approach that of current developed countries.

Developing countries are skeptical that any World Bankadministered fund would give their opinions adequate consideration. "Much of this scepticism emerged after the initial discussions leading to the formation of GEF, which took place only between participating agencies and contributing countries, and which did not involve developing countries."64 Spurned once by the GEF, China and other developing countries are reluctant to give the World Bank administrative control of clean technology funds.

That skepticism may be well founded, but large developing countries with large economies are interested in more than just representation in a clean technology fund. They stand to gain more financial support from clean technology funds than any other group. The sheer size of their economies means that they will have to initiate many clean technology

61. E.g., Implementation of the Bali Roadmap: China's Position on the Copenhagen Climate Change Conference, PERMANENT Mission OF THE PEOPLE's REPUBLIC OF CHINA TO THE UN (May 20, 2009), http:/www.china-un.org/eng/chinaandun/economicdevelopment/climatechange/ t568959.htm (The Chinese government has released a statement, which states that "to effectively operationalize the financial mechanism under the UNFCCC, . . a Multilateral Technology Acquisition Fund . . . shall be established. The governance of these Funds should be under the authority and guidance of the COP with equitable and balanced representation of all Parties in a transparent and efficient manner.').

62. See G-77, Proposal by the G-77 \& China for A Technology Mechanism under the UNFCCC 1-2, UNFCCC, http//unfccc.int/files/meetings/ad_hoc_working_groups/lca/application/ pdf/technology_proposal_g77_8.pdf.

63. BAUMERT, supra note 59 , at $18,22$.

64. Ramakrishna \& Young, supra note 55, at 263. 
projects to achieve even a small reduction in their overall GHG emissions.

Also, countries like China, India, and Brazil may be better candidates for funding because they are more developed than other developing countries. Donor countries will want to ensure that their money goes to projects that verifiably reduce emissions. The effect of one metric ton of carbon dioxide produced in China is essentially the same as one metric ton of carbon dioxide produced in Uruguay. Therefore, to determine which developing countries should receive funding, the administrator of the fund will likely favor countries that can better track emissions reductions. Because countries like China, India, and Brazil are more developed, they will likely have access to the technologies and managerial skills needed to report and track the results of clean technology fund projects.

The interest of China, India, and Brazil in representation and funding does not mean that these countries are not also interested in forestalling climate change. They are all highly susceptible to its effects. For example, according to some predictions, climate change will greatly reduce water resources throughout China, and northern and western China will be especially affected. ${ }^{65}$ Also, per capita GDP in China, India, and Brazil is still fairly low, meaning that some population segments of these countries could have difficulty adapting to the effects of climate change. Therefore, both a desire for aid money and an interest in efficiently mitigating climate change are likely guiding motivations for these countries.

\section{Least Developed Countries and Small Island States}

Small island states and the least developed countries are particularly concerned about the effect climate change will have on their countries. Most of the small island states are represented in climate change talks by an organization called the Alliance of Small Island States (AOSIS). ${ }^{66}$ The fifty countries designated by the United Nations as LDCs work together in what is known as the Group of LDCs. Both

65. See Nat'L Dev. AND Reform Comm'n ChIna, China's Nattonal Climate Change PROGRAMME, 17-18 (2007), available at http:/en.ndrc.gov.cn/newsrelease/P02007060456119 1006823.pdf.

66. See About AOSIS, AOSIS, http://www.sidsnet.org/aosis/about.html (last visited Oct. 18, 2010) (The Alliance of Small Island States (AOSIS) is a coalition of small island and low-lying coastal countries that share similar development challenges and concerns about the environment, especially their vulnerability to the adverse effects of global climate change. It functions primarily as an ad hoc lobby and negotiating voice for small island developing States (SIDS) within the United Nations system."). 
AOSIS and the Group of LDCs have expressed support for a COP-led fund ${ }^{67}$

Although some members of AOSIS are also LDCs, many of the countries in the two groups have drastically different economic and political environments. For example, the U.S. Virgin Islands, a small island state, has more than fifty times the per capita income of GuineaBissau, which is an LDC. ${ }^{68}$ Despite these differences, both groups are particularly susceptible to the negative impacts of climate change. Small island nations like Tuvalu face the frightening possibility that the rising sea will swallow the country. ${ }^{69}$ LDCs like Burundi and GuineaBissau are often equally cursed by geography, but their extremely low GDP prevents them from making adequate investments in climate adaptation projects.

Although small island nations and LDCs are highly susceptible to climate change, neither group is likely to receive substantial aid for clean technology, nor is this their motivation. Compared to large developing countries like China, India, and Brazil, small island states and LDCs have low GDPs, ${ }^{70}$ relatively low GHG emissions, ${ }^{71}$ and, at least for some LDCs, a lack of infrastructure and government accountability. Clean technology fund projects will most likely take place in countries that are rapidly industrializing but still have high GHG emissions from outdated technology. If a country already has very low emissions, like most small island states and LDCs, clean technology funding would be of little use. Both AOSIS and the Group of LDCs have been active in advocating for a clean technology fund administrator

67. Nicola Cantore et al., Climate Negotiations and Development: How Can Low-Income Countries Gain from a Climate Negotiation Framework Agreement? 3 (Overseas Dev. Inst., Working Paper No. 312, 2009), available at http:/wwww.reliefweb.int/rw/lib.nsf/db900sid/ASAZ. 7YADCS/\$file/ODI_Nov2009.pdf?openelement ("The LDC Group and AOSIS supports [sic] the China proposal for a technology window, established in the new financial mechanism under the control of the COP, which shall support implementation of concrete and practical technology activities.").

68. Compare Data of Virgin Islands (U.S.), WORLD BANK, http://data.worldbank.org/ country/virgin-islands-us (last visited October 18, 2010) (showing per capita Gross National Income of $\$ 13,660$ ) with Data of Guinea-Bissau, WORLD BANK, http:/data.worldbank.org/ country/guinea-bissau (last visited October 18, 2010) (showing per capita Gross National Income of $\$ 250$ ).

69. Tuvalu and Global Warming, TUVALU ISLANDS, http:/www.tuvaluislands.com/ warming.htm (last visited Oct. 18, 2010).

70. World Factbook, Country Comparison: GDP - Per Capita, CIA, https:/www.cia.gov/ library/publications/the-world-factbook/rankorder/2004rank.html (last visited Oct. 27, 2010).

71. See Sixth Compilation and Synthesis of Initial National Communications From Parties Not Included in Annex I to the Convention, Subsidiary Body for Implementation, UNFCCC, 23d Sess., Nov. 28, 2005-Dec. 6, 2005, para. 38, U.N. Doc. FCCC/SBI/2005/18/Add.2, (Oct. 25, 2005), available at http//unfcoc.int/documentation/documents/advanced_search/items/3594.php?rec= j\&priref $=600003580$ \#beg. 
through the COP, but it is unlikely that these groups are setting themselves up to become primary clean technology fund aid recipients.

The vulnerability of small island states and LDCs, however, makes them excellent candidates for adaptation aid. Their support of the COP to administer clean technology funds could be a calculated move to convince large countries like China, India, and Brazil to support the efforts of AOSIS and the Group of LDCs to have the COP control adaptation funds. LDCs and small island states have more influence in the COP than with the World Bank, so they are likely to want the COP to control adaptation funds. LDCs and small island states could be engaging in some kind of quid pro quo with large developing countries that want the COP to control clean technology funds. However, it is somewhat of a stretch to assume that small island states and LDCs would put all their eggs in the adaptation basket. The more likely explanation is that small island states recognize that adaptation to climate change will only get them so far and that they need a climate change strategy that emphasizes both adaptation and mitigation. Their support for a COP-created fund over the CTF is most likely based on their assumption that a COP.created fund would be more successful in mitigating climate change. As they stand to lose the most from the effects of climate change, the views of AOSIS and the Group of LDCs are not unbiased, but they are probably the most consistent with what should be the goal of a clean technology fund-mitigating climate change.

\section{The COP Should CONTROL CleAN TECHNOLOGY AID}

While the previous section examined why different countries support either the COP or the World Bank's CTF as administrator, this section compares the administrators based on efficiency, ethics, and politics, and considers whether there is a better way to administer funds. Based on this analysis, I conclude that the World Bank's CTF suffers from several important flaws that make it an unviable option. Unless the World Bank's CTF is reformed, the COP should create a new institution to administer clean technology funds.

\section{A. Comparing the COP to the CTF}

As I mentioned earlier in this Note, it is difficult to draw a full comparison between the CTF and a COP-created fund because the final structure of a COP-created fund is only hypothetical. Nonetheless, we can theorize about what a COP-created fund would look like based on the expressed interests of the stakeholders in the COP process and past 
United Nations' experience with international aid mechanisms. While I believe this type of comparison is useful, this section of the Note can also be thought of as simply a critique of the World Bank's CTF. Specifically, this section examines the issues both organizations face with regard to governance and procedural fairness, environmental concerns, past administrative experience, and how the selection of each fund would impact other goals of a climate change treaty.

\section{Governance and Procedural Fairness}

To avert climate change, developing countries will need to reduce their GHG emissions in the long run. However, they will not agree to firm emissions reductions without an equitably structured clean technology fund. For this reason, equitable governance is perhaps the most important criteria for evaluating a clean technology fund. This section provides a comparative evaluation of the governing structure of the COP process and the World Bank's CTF.

Equitable governance can mean different things to different countries. For donor countries, this might require that they have final say in what projects receive clean technology aid because they want verification of how their money is being used. After all, a clean technology fund would not exist without the donors' contributions. For developing countries, equitable governance might mean that countries that are eligible to receive clean technology fund aid should decide among themselves who should receive funding. In this instance, clean technology fund aid would essentially be compensation to developing countries for harm caused by developed countries' emissions. Alternatively, equitable governance might mean that countries with the lowest per capita GHG emissions should be given decision-making authority. As discussed previously, countries with the lowest per capita emissions are generally the least developed countries, and those countries are likely to suffer the most harm from climate change.

All three are reasonable ethical viewpoints, and, practically speaking, the COP is unlikely to select a fund administrator or create a fund that only considers one group's views. Without the donors' support there will be no money, yet developing countries are unlikely to agree to reduce their own future GHG emissions if they are not given adequate say in the administration of the clean technology fund. Rather than arbitrarily choosing among each group's definition of equitable governance, the more prudent approach is simply to recognize that each group has a justifiable argument and that a clean technology fund administrator should therefore operate on a consensus basis. This means that developed country donors and developing country donees 
should have equal voting rights and that developing countries of all economic statuses should be allowed trustee, or voting, status for the clean technology fund on a rotating basis.

Unfortunately, what is equitable is not necessarily efficient, and, admittedly, this approach creates some efficiency and collective action problems. Many stakeholders and countries will want to weigh in on the process of choosing a clean technology fund administrator. In the seminal work, The Logic of Collective Action, Mancur Olson noted the difficulty large groups have in cooperating, even in instances where the members of the group would all be made better off if they did.72 Fortunately, the COP does not seem as doomed to failure as the groups Olson evaluates. Olson notes that the prohibitively high costs of organization can inhibit collective action, but where a group has already been formed, many of those organizational costs have already been paid. ${ }^{73}$ Because the COP is a relatively mature international institution, new, additional costs attributable to the negotiation of a clean technology fund administrator are unlikely to inhibit negotiations. Also, in many ways the COP is not such a large group. As this Note has discussed in detail, the individual parties to the COP have formed negotiating blocks. Developing and developed countries generally express themselves through a few organizations, and by forming these coalitions, the parties to the COP have made it easier to find consensus.

While developing countries believe the COP process is equitable, the more surprising discovery is that developed countries have not disputed the equity of the COP process. In fact, developed countries have been willing participants in many aspects of the COP process. For instance, they helped draft the Copenhagen Accord, ${ }^{74}$ and even the World Bank's CTF Governance Framework defers, at least in theory, to the equitable superiority of the COP process. ${ }^{75}$ However, because equitability is not in the financial self-interest of developed countries, many of them remain unwilling to use the COP to develop a clean technology fund, and instead prefer the World Bank's CTF.

The organization of the World Bank's CTF is based on the Governance Framework (the Framework) established in November 2008. The Framework creates the CTF Trust Fund Committee (the

72. Mancur Olson, The Logic of COLlective ACtion: PUblic GoOds AND the THEORY of GROUPS 48 (1965).

73. $I d$. at $46-48$.

74. Darren Samuelsohn, Obama Negotiates 'Copenhagen Accord' with Senate Climate Fight in Mind, N.Y. TTMES (Dec. 21, 2009), http:/www.nytimes.com/cwire/2009/12/21/21climatewireobama-negotiates-copenhagen-accord-with-senat-6121.html.

75. Climate Inv. Funds, Clean Technology Fund Governance Framework, paras. 6, 53-56 (November 2008) [hereinafter Governance Framework], available at http//siteresources. worldbank.org/ INTCC/Resources/CTF_Governance_Framework_jan.pdf. 
Committee), the board responsible for all fund decision making. The Committee is made up of eight representatives from contributor countries and eight representatives from countries eligible to receive funds. ${ }^{76}$ Each representative has equal voting power, so contributor and recipient countries receive an equal number of votes. Based on the collective action problems discussed above, it is wise to limit the number of trustees. If the COP creates a new fund, it should adopt a scheme similar to this aspect of the World Bank's CTF.

The Committee's voting process also acts as a safeguard against the collective action problems. Decisions must be made by the consensus of decision-making members, where no participant decides to block the proposed decision. ${ }^{77}$ However, consensus does not necessarily imply unanimous support. A dissenting member can either choose to block the decision or let the decision go forward with a statement objecting to all or part of the decision. If a dissenter chooses to block the decision, the decision must be postponed or withdrawn. ${ }^{78}$ Consensus voting seems to be a fair approach to decision making, but other sections of the Framework put the fairness of the overall World Bank's CTF structure in doubt.

The Framework suffers from three primary problems. First, the selection process for recipient countries to hold a position on the Committee is potentially inequitable. The Framework states that recipient countries for the Committee will be "identified through a consultation among interested eligible recipient countries." 79 After the Framework was developed, some commentators noted that because the consultation process is vague, it could be implemented in a way that marginalizes some recipient countries seeking a position on the Committee. ${ }^{80}$

The CTF recently held its Partnership Forum, in which new members of the trust fund committee were selected. It also released a note that responded to these criticisms by providing some additional details about the selection process. ${ }^{81}$ The recipient country members decided that six of their seats would be allocated on a regional basis, where recipient countries for each of the World Bank's six designated

76. Id. at para. 19 (a)-(b).

77. Id. at para. 27.

78. Id.

79. Id. at para. 19 (b).

80. Addie Haughey, Note, The World Bank Clean Technology Fund: Friend or Foe to the UNFCCC?, 9 SustaINABLE DEv. L. \& PoL'Y 57, 59 (Winter 2009).

81. Climate Inv. Funds, Note on the Selection of Members to the CTF and SCF Trust Fund Committees and PPCR Sub-committee (Mar. 17, 2010), available at $\mathrm{http} / / \mathrm{www} . c$ limateinvestmentfunds.org/cif/node/1155. 
regions will select a representative. ${ }^{82}$ The recipient countries decide together on the two remaining seats. ${ }^{83}$ Apart from the emphasis on regional representation, no written requirements exist for how countries are selected. The lack of a formal written process is troubling. Moreover, whatever unwritten process is used seems to favor large developing countries with large emissions over the least developed countries and small island states. The developing countries that are Committee members are India, China, Mexico, Brazil, South Africa, Morocco, Nigeria, and Egypt; however, no LDCs or small island states are on the Committee. To be fair, the SCF, the World Bank's adaptation fund, does include some LDCs, but at least some representation for LDCs and small island states should be on both Committees-the CTF and the SCF.

The Framework's second problem is that the Committee's authority to assign funding to projects is subject to two important restrictions. First, it is possible the CTF Framework would allow contributor countries to condition donations to the CTF through their trust fund administration agreements. In addition, "the executive directors of the World Bank or any other multilateral bank involved in a specific project must still approve specific projects." ${ }^{44}$ Unlike the Committee, the World Bank does not give equal voting rights to both contributor and recipient countries. ${ }^{85}$ The Bank Information Center, an independent group that monitors the Bank, has described the Bank's voting process as a "onedollar-one-vote" system, with developed countries retaining the bulk of decision-making power. ${ }^{86}$ Both of these constraints prevent the Committee from exercising full autonomy and shift the balance of power back in favor of developed countries.

The third problem, and perhaps the most worrisome, is the sunset clause of the CTF Governance Framework. The sunset clause is not a problem in and of itself, but, if the COP designs a better clean technology fund than the CTF, the sunset clause could become a problem. The clause reads,

[T]he CTF will take necessary steps to conclude its operations once a new financial architecture is effective.

82. Id. at para. 5 .

83. Id. at para. 7(b).

84. Downes, supra note 15 , at 855.

85. See Int'l Bank of Reconstr. and Dev. Articles of Agreement art. V, sec. 3(a), Feb. 16, 1989, available at http//siteresources.worldbank.org/EXTABOUTUS/Resources/ibrd-articles ofagreement.pdf ("Each member shall have two hundred fifty votes plus one additional vote for each share of stock held.").

86. World Bank (IBRD \& IDA), BANK INFO. CENTER, http:/www.bicusa.org/en/ Institution.Structure.5.aspx (last visited Oct. 18, 2010). 
The Trustee will not enter into any new agreement with contributors for contributions to the CTF once the agreement providing for the new financial architecture is effective. The CTF Trust Fund Committee will decide the date on which it will cease making allocations from the outstanding balance of the CTF. ${ }^{87}$

Initially, this appears to be a very positive step for the CTF. The Governance Framework acknowledges that the CTF should not undermine the COP process. However, determining when "a new financial architecture is effective" is highly subjective, and the CTF may not want to stop lending at the request of COP. This might only work as a short-term strategy, but establishing an "effective" fund will certainly be difficult if contributions continue to be funneled to the CTF rather than a COP-created fund. Ultimately, the Bank's claims that the CTF is only an interim measure do not seem genuine. ${ }^{88}$

\section{Environmental Concerns}

Another contentious aspect of selecting a clean technology fund administrator is how the administrator will define "clean technology" when deciding which projects to fund. In Foreign Policy magazine, Phil Radford, the Executive Director of Greenpeace, and Jamal Saghir, the World Bank's Director of Energy, Transport, and Water Programs, debated the World Bank's approach to combating climate change. Radford noted that in 2004 the World Bank's Extractive Industries Review advised the World Bank to formalize a moratorium on lending for coal projects. The World Bank, however, rejected that suggestion and, between 2007 and 2009, increased funding for coal projects by nearly $200 \% .{ }^{89}$ In fact, the World Bank recently approved a $\$ 3.75$ billion loan to build a 4,800 megawatt coal-burning power plant in South Africa. ${ }^{90}$ The plant, which would be one of the largest coal-burning plants in the world, has sparked a great deal of anger in the environmental community, who believe it is disingenuous for the World Bank to posture itself as a leader in climate finance while still providing loans to highly GHG intensive projects. ${ }^{91}$

87. Governance Framework, supra note 75, at para. 53.

88. Haughey, supra note 80 , at 60 .

89. Phil Radford, Banking on Coal, Foreign PoLicy (Dec. 9, 2009), http $/ /$ www.foreignpolicy.com/articles/2009/12/09/banking_on_coal.

90. Lisa Friedman, Eskom Fallout Spurs New Opposition to World Bank's Role in Climate

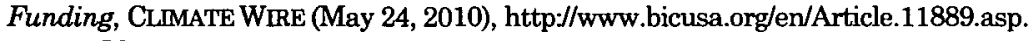

91. Id. 
Radford's primary objections to the World Bank's action were the following: (1) coal is the most carbon-intensive form of energy generation (without carbon capture and sequestration) and sustainable alternatives to coal exist that can be implemented on a commercial scale; (2) "between 6,000 and 10,700 annual deaths can be attributed to the 88 coal-fired power plants and companies receiving public international financing, including from the World Bank"; and (3) although utilizing coal-fired energy may save money in the short-term, coal-fired power plants are built to last for decades, and their GHG emissions could make them a significant liability, both financially and environmentally, in the future. ${ }^{92}$ As the developing world's energy consumption rises, developing countries will have to start reducing their GHG emissions long before their new coal-fired power plants are decommissioned.

On behalf of the World Bank, Saghir opined that: (1) in 2009, the World Bank financed more renewable energy and energy efficiency projects than fossil fuel projects; (2) the aforementioned new power plant being constructed in South Africa with a World Bank loan will use supercritical coal technology, which is more efficient than traditional coal-fired plants, and "has $\$ 750$ million in financing for renewable energy and low-carbon energy efficiency components that otherwise would not be part of the project"; and (3) utilizing least-cost power resources is essential to increase the standard of living in the developing world. ${ }^{93} \mathrm{He}$ concluded that, "[u]nder very limited, case-bycase situations with strict criteria, and when alternative lower-carbon technologies are not immediately available, we will support least cost, carbon-based energy solutions."94

On its face, Saghir's arguments seem well reasoned, but his response contains several problems. Saghir did not respond to Radford's assertion-supported by a report from the Environmental Defense Fund ${ }^{95}$ _. that coal-fired power plants built with World Bank loans have resulted in an unacceptably high death toll due to conventional pollution in the air and water. Also, there are important definitional problems with what the Bank classifies as low-carbon and energy efficient. The Environmental Defense Fund, in the same report previously mentioned, found that the World Bank considers funding for

92. Radford, supra note 89 .

93. Jamal Saghir, The World Bank Responds to Greenpeace, FoREIGN PoLJCY (Dec. 11, 2009), http://blog.foreignpolicy.com/posts/2009/12/11/the_world_bank_responds_to_greenpeace.

94. Id.

95. Bruce Rich, Envtl. Def. Fund, Foreclosing the Fúture Coal, Climate and Public INTERNATIONAL FINANCE 1 (2009), available at http:/www.edf.org/documents/9593_coal-plantsreport.pdf. 
supercritical coal-fired technology as "low-carbon," 96 making the World Bank's claim that the new South African plant will have $\$ 750$ million in low-carbon and energy efficiency components misleading.

Although the World Bank's CTF did not fund the South African power plant, the CTF's regulations do allow countries to receive CTF financing for supercritical coal-fired power plants. ${ }^{97}$ Supercritical coalfired power plants are approximately fifteen percent more efficient than regular coal plants, but they still emit, over several decades, millions of tons of GHGs. 98 The World Bank and other multilateral development banks have claimed that these coal projects would be built without additional bank financing, but that the power plants would not install more efficient coal-burning technology without this additional financing. ${ }^{99}$ While this argument is plausible, evidence suggests that the World Bank's assumption is incorrect. Supercritical coal-fired plants are already economical in India and are likely economical in other developing countries as well. ${ }^{100}$ For example, a 2007 Massachusetts Institute of Technology study entitled "The Future of Coal" concluded that because of reduced operating and fuel costs, the cost of delivered energy from a supercritical plant is lower than from a traditional plant. 101

Clean technology aid is a scarce resource, and it should be used to fill the void in finance for more advanced low-carbon energy projects. There is a great deal more capital already available for traditional fossil fuel projects than for low-carbon energy projects. ${ }^{102}$ The World Bank should be using CTF funds to build new low-carbon energy sources. Many of the developing countries in which projects will take place need access to capital and financial stability so that workers will invest in the skills needed for future energy projects. Furthermore, if more money is funneled into low-carbon energy projects, competition for those funds between energy project developers would increase. This competition will spur technological advancements and cost reduction strategies as firms try to develop more efficient energy projects.

96. Id. at 16 .

97. Id.

98. See id. at 17-18.

99. Id. at 17 .

100. Id. (noting that a U.S.-based energy company is planning to build a 1,000 megawatt solar thermal array in India's Gujarat State without funding from the World Bank).

101. Id.

102. See Russell Gold, Finding Financing: Renewable Energy Struggles, Banks Embrace Fossil Fuels, WALl ST. J. BLOG: ENVTL. CAPTTAL (Apr. 24, 2009, 1:16 PM), http://logs.wsj.com/ environmentalcapital/2009/04/24/finding-financing-renewable-energy-struggles-banks-embracefossil-fuels. 
Saghir makes an important point in that providing low-cost electricity in developing countries is essential to reducing poverty, but all pertinent costs in making that determination must be considered. The World Bank must consider the loss of human life and health, as well as environmental damage, from conventional pollutants emitted from coal-fired power plants and from GHG emissions that contribute to climate change. The World Bank must also consider whether investments in coal-fired power plants are good in the long-term, when developing countries will also have to reduce their GHG emissions. Saghir states in his response that the World Bank engages in this indepth analysis, but if that is true, the World Bank must do a better job of explaining its analysis to the public.

The World Bank could choose to change its lending practices to make its CTF a more attractive option for selection by the COP. In some instances, coal projects may be the best financial and environmental investment-like integrated gasification combined cycle coal plants with carbon capture and sequestration-but the World Bank must be willing to provide an honest assessment of their energy investments and significant proof that other renewable and low-carbon energy options have been given due consideration before providing funding for coal.

\section{Experience Administering Similar Funds}

The United Nations has experience administering a fund very similar to the clean technology fund proposed for GHG emissions. The United Nations assists administration of the Multilateral Fund for Implementation of the Montreal Protocol (the Fund). ${ }^{103}$ Although the Fund has had some shortcomings, in general, it has been considered a success. 104

While the World Bank, along with the U.N. Environment Program (UNEP), the U.N. Development Program (UNDP), and the U.N. Industrial Development Organization (UNIDO), played an important

103. See Memorandum from Friends of the Earth on U.S. Funding for Clean Technology Under the U.N. Climate Convention in 2010, U.S. CLIMATE NETWORK (Mar., 2009), available at http:/www.usclimatenetwork.org/resource-database/3-

09\%20unfccc\%20clean\%20tech\%20final.doc.

104. James Andrew Bove, A Study of the Financial Mechanism of the Montreal Protocol on Substances That Deplete the Ozone Layer, 9 ENVTL. LAw. 399, 410 (2003) (The Fund has been highly successful, with over $\$ 1.6$ billion pledged (through 2002 ) to assist parties "in meeting the requirements of the Protocol. The Executive Committee has approved the distribution of US \$1.2 billion for roughly 3,850 projects and activities in 124 developing countries . . . [C]urrently approved projects will account for the phase out in consumption of ODS that would have destroyed over 142,000 tons of ozone and the phase out in production of ODS that would have destroyed about 44,200 tons of ozone."). 
role in implementing the Fund, ${ }^{105}$ the World Bank was not selected to direct the policies and framework of the Fund. The Fund Secretariat and an Executive Committee that was established by the Montreal Protocol each partly administer the Fund. ${ }^{106}$ Although the Fund is admittedly much smaller than what would be necessary for a climate change clean technology fund, it is still useful as a foundational model.

\section{Effect on Negotiations of a Multilateral Climate Change Treaty}

The finance ministers of Japan and the United Kingdom, along with former U.S. Treasury Secretary Henry Paulson, stated that they believe providing money to the World Bank's CTF is the best way to kick start international aid for clean technology funding. ${ }^{107}$ The World Bank's CTF may have brought more attention to clean technology aid than there would be otherwise, but the CTF may also be a new impediment to negotiations about clean technology funding. In addition to determining the proper structure of a clean technology fund, the COP may have to find a way to funnel financing away from the CTF and back into a COPcreated fund. Although this should not be as challenging for new financing, the World Bank's CTF could potentially receive billions of dollars from donor countries before a new COP-led fund is established. Also, the knowledge and investment in human capital created in the World Bank through the operation of its CTF will likely be lost when a new clean technology fund administrator is established. If, instead, a U.N. fund like the SCCF held the CTF's assets, the COP could more easily shift staff and other resources to a new COP-led fund created by a multilateral climate change treaty than it could move resources from the World Bank to a new COP fund.

Developed countries have removed an important bargaining chip from the table. If they were more willing to negotiate over a clean technology fund administrator, rather than unilaterally support the World Bank for that role, they would have leverage with developing countries on other important issues. For example, developed countries want commitments from developing countries that they will reduce their emissions. However, developing countries want funds to offset the costs of a transition to a low-carbon economy and an organization they can trust to administer the funds. The only way both groups can achieve their objectives is if they have a chance to negotiate. If developed countries unilaterally decide that the World Bank's CTF is going to be

105. Id. at 414-19.

106. Id. at 411-14.

107. Paulson, supra note 26. 
the clean technology mechanism, they should expect that developing countries are going to be resistant to binding emissions cuts.

\section{B. Alternative Approaches to a Single Clean Technology Fund Administrator}

So far this Note has assumed that having one organization administer the clean technology fund is preferable, and that either the World Bank or the COP, but not both, should administer the clean technology fund. To address any lingering questions about why that assumption is logical, this section looks at two possible alternatives.

The first alternative is for the World Bank and the COP to be joint administrators of the clean technology fund. However, requiring two different organizations with different goals to decide together on policy objectives seems highly inefficient and problematic. If they agreed to jointly administer a clean technology fund, they might use the GEF to provide administrative support. In some ways, the GEF represents a middle ground between the two organizations. Even though the GEF receives policy advice from the UNFCCC, it is in charge of its own dayto-day operations. The World Bank founded the GEF and is one of three implementing agencies-along with the UNEP and the UNDP. The Bank's role as an implementing agency includes being the "[t]rustee of the GEF Trust Fund and provid[ing] administrative services." 108 As a result of this administrative relationship, developing countries are skeptical of the GEF. ${ }^{109}$ While using the GEF could help the COP and the World Bank find common ground on implementation, there is no reason to think the GEF will be able to align the COP's and the World Bank's goals for how the fund should be set up and what its general policies should be. Ultimately, even if the World Bank and the COP used the GEF for implementation, they would still be put in the difficult position of having to make joint decisions about the structure of the clean technology fund.

The second alternative is to have more than one fund administrator. Having multiple funds could provide some benefits. For example, competition for the most desirable projects could drive down interest rates on clean technology loans. Also, competition to receive funding from donor countries could drive competing funds to lower administrative costs and increase their efficiency. However, multiple funds create some problems. First, if there are many different funds with different procedures, ensuring that all funds are administered in a

108. GEF, supra note 20.

109. Hunter, supra note 9, at 262-63. 
manner consistent with the principles of the UNFCCC will be much more difficult. Second, having a single fund would ensure a uniform application process and reduce the burden on project developers in developing countries who would otherwise have to learn the administrative procedures of each separate fund before applying for a loan. Third, high barriers to entry to compete for administration of clean technology funds ${ }^{110}$ make it unlikely that there will be contenders for fund administrator other than the World Bank and the COP. Although plenty of room still exists for private finance of clean technology projects, the high barriers to entry for public finance of clean technology projects reduce the likelihood that there will be any new entrants in the competition.

The costs and difficulties of each alternative appear to overshadow their benefits. Therefore, the most likely outcome is that only one clean technology fund will prevail and that the COP and the World Bank will not jointly administer the fund.

\section{Conclusion}

To recap, the World Bank's CTF suffers from several important flaws. Its financing of coal-fired power plants is questionable, and its structure does not guarantee equal representation for developing countries, particularly LDCs. On the other hand, the United Nations has experience setting up a similar clean technology framework for the Montreal Protocol. Moreover, developing countries are more likely to agree to emissions reductions in a multilateral climate change agreement if they have a voice in what institution becomes the clean technology fund administrator. It may be more difficult for all the countries of the COP to come to an agreement on the structure of a clean technology fund, but the coalitions that developed and developing countries have formed to negotiate a climate change treaty should help reduce transaction costs. To prevent collective action problems, a COPled fund should mimic the World Bank's CTF and have a small number of trustees that are appointed on a rotating basis so that all members of the COP could eventually participate.

As the World Bank's CTF is currently structured, it should not be selected as the permanent clean technology fund administrator, and it is unlikely that it would be selected by the COP. Yet, the World Bank's CTF could be reformed to stop lending for coal projects-except perhaps

110. Barriers to entry would include political obstacles, like attaining international legitimacy, and also requirements of institutional capacity to connect with numerous stakeholders to deal with global problems. 
under the most compelling circumstances-and to more adequately represent the interests of the least developed countries that are critically impacted by climate change. If the World Bank accomplishes this goal, the COP could reasonably select it as permanent clean technology fund administrator. Conversely, if the World Bank does not make these reforms, a new COP-created fund would be a better alternative.

\section{THE LEGAL AUTHORITY OF THE UNITED NATIONS OVER THE WORLD BANK'S CTF}

Having looked at the different interest groups, their arguments over clean technology funds, and the merits of those claims, the COP appears to be the best organization to design and administer a clean technology fund. If the COP creates this new fund, the World Bank's CTF should cease operating. If developed and developing countries support a new COP-created fund, donor countries may naturally stop financing the CTF. That would be the simplest way for the CTF to cease operations. Alternatively, the World Bank may voluntarily end its CTF when a new fund is established. Commentators have noted that "[t]he Bretton Woods institutions, recognizing that legitimacy depends on acting within the UN legal order, have increased their cooperation and consultation with the United Nations." 111 However, there is no guarantee the World Bank's CTF will shut down so easily.

The World Bank may argue that the CTF should be retained as a secondary clean technology fund. If some developed countries agree with the World Bank's idea, they may split their contributions between the CTF and a COP fund, thereby diverting important resources from the better aid mechanism. As this Note earlier concluded, the CTF as currently organized and a COP-led fund would not function well together. If the World Bank's decision to the keep the CTF open attracts donor countries away from the COP fund, another question arises: Would the United Nations have any recourse against the CTF and its donors?

Since its inception, the World Bank has fiercely guarded its independence. During initial negotiations with the Economic and Social Council of the United Nations (ECOSOC), the U.N. body that adopts specialized agencies under Articles 57 and 63 of the U.N. Charter, the World Bank seemed uninterested in joining the United Nations. "The [World] Bank was very fearful that becoming a specialized agency of the

111. Nigel D. White, The UNTTED NATIONS System: Toward INTERNATIONAL JUSTICE 268 (2002). 
United Nations would subject it to undesirable political control or influence and hurt its credit rating in Wall Street . . .."112 Eventually, the World Bank decided to join the United Nations, but the agreement the World Bank initially drafted was seen as "more a declaration of independence from than cooperation with the United Nations."113 After negotiations with the United Nations over the draft agreement, the World Bank agreed to some concessions in the language. Nevertheless, the final agreement still clearly favors the World Bank's autonomy.

Under the agreement, known as Resolution 124 (II), the World Bank "is, and is required to function as an independent international organization." 114 It only has to give "due consideration to the inclusion in the agenda of items proposed by the United Nations." 115 Also, the United Nations may only appropriately make "recommendations" about technical aspects of World Bank programs or projects. ${ }^{116}$ The ECOSOC was given authority under the charter to define the terms of the relationship between the specialized agencies it brought in, and it defined the terms favorably to the World Bank. After the U.N. General Assembly's approval of the agreement in accordance with Article 63, there is little basis to challenge the World Bank's independent status.

If the United Nations cannot challenge the World Bank's autonomy directly, then the next best route is to challenge the countries that are members of the World Bank's CTF. The U.N. Charter provides some explanation of the hierarchy between the United Nations and its specialized agencies. Article 103 of the U.N. Charter states, "In the event of a conflict between the obligations of a Member of the United Nations under the present Charter and their obligations under any other international agreement, their obligations under the present Charter shall prevail." 117 This hierarchy of agreements is imposed on the states, rather than on the subsidiary organizations directly, ${ }^{118}$ but the Charter does not create any obligation for donor countries to leave the CTF, either in explicit terms-because the Charter was created long before the CTF-or in more abstract terms.

However, recourse may be had through the CTF's donor countries. Under the UNFCCC treaty, developed countries have an obligation to provide clean technology financing for developing countries according to

112. EdWARD S. MASON \& ROBERT E. ASHER, THE WorLd Bank Since BRETTON WOODS 56 (1973).

113. Id. at 57 .

114. Agreement between UN and IBRD, supra note 11, at 198, art. I, para. 2.

115. Id. at 199, art. III.

116. Id. at 199, art. IV para. 4.

117. U.N. Charter art. 103.

118. WHTTE, supra note 111, at 12. 
certain principles. Under Article 11, those principles include accountability to the COP and "an equitable and balanced representation of all Parties within a transparent system of governance."119 The World Bank could argue that the structure of its CTF includes equitable representation and that its sunset clause makes it in effect accountable to the COP, but, as section II of this article determined, this argument is not convincing. Because of discrepancies between the CTF Governance Framework and the UNFCCC, it has been argued that contributions to the CTF should not count toward developed countries' obligations under the UNFCCC. ${ }^{120}$ This argument does not restrict what the CTF itself does, but it would put donor countries in noncompliance with the UNFCCC.

One final argument is that the sunset clause of the World Bank's CTF provides that the CTF will stop financing new projects when a new financial architecture is effective. Because "effective" is an ambiguous term, this language does not provide a guarantee that the World Bank will shut down the CTF. The COP could argue that the fund is effective when a new climate change treaty is drafted and that the World Bank's CTF should conclude its operations at that time. However, the decision to conclude operations of the fund ultimately rests with the CTF Trust Fund Committee, not the COP.

These legal arguments indicate that it is unlikely the United Nations could force the World Bank to stop operating the CTF. The terms of the World Bank's relationship with the ECOSOC and the United Nations give it significant autonomy and, in this instance, do not create a duty to the United Nations. Under the CTF's Framework there is a legal duty to shut down the CTF when the COP has created a new clean technology fund, but the timeframe in which the CTF must be shut down is ambiguous and would allow the CTF to continue operating at least in the short term after a new fund is created. The best legal argument the COP has is that donations to the CTF do not satisfy a country's obligations under the UNFCCC treaty, but the UNFCCC treaty lacks an enforcement mechanism. Thus, something other than legal arguments is needed for the COP to prevail in a future dispute over the CTF.

\section{CONCLUSION}

One key component of a successful climate change treaty will be an agreement between developed and developing countries on international

119. UNFCCC, supra note 48 , at art. 11.

120. See Haughey, supra note 80. 
aid for clean technology. Moreover, for a climate change treaty to be successful, the treaty must consider the views of LDCs and small island states. The World Bank's CTF is by no means fatally flawed, but, as it is currently structured, a sufficient guarantee that voting rights for the Trust Fund Committee will be equitably divided to include the poorest nations is noticeably missing. The World Bank also has a history of funding massive coal projects without providing sufficient evidence that the favorable terms of public loans were necessary to get those projects off the ground. The CTF leaves the door open for the World Bank to finance more coal projects in the future and does not provide enough assurance that renewable energy and energy efficiency projects are being given due consideration. Unless the World Bank reforms its CTF, the COP should develop a new clean technology fund to take the CTF's place. 
